\title{
The Pickett Switch Site (34PN1) and the Presence of Arkansas River Basin Caddoans in East Central Oklahoma
}

Robert L. Brooks

Unknown

Follow this and additional works at: https://scholarworks.sfasu.edu/ita

Part of the American Material Culture Commons, Archaeological Anthropology Commons, Environmental Studies Commons, Other American Studies Commons, Other Arts and Humanities Commons, Other History of Art, Architecture, and Archaeology Commons, and the United States History Commons

Tell us how this article helped you.

This Article is brought to you for free and open access by the Center for Regional Heritage Research at SFA ScholarWorks. It has been accepted for inclusion in Index of Texas Archaeology: Open Access Gray Literature from the Lone Star State by an authorized editor of SFA ScholarWorks. For more information, please contact cdsscholarworks@sfasu.edu. 


\section{The Pickett Switch Site (34PN1) and the Presence of Arkansas River Basin}

Caddoans in East Central Oklahoma

\section{Creative Commons License}

\section{(c) (1) \&}

This work is licensed under a Creative Commons Attribution-NonCommercial 4.0 International License 


\title{
The PicketT SWITCh Site (34PN1) AND The PRESENCE OF ARKansas River BaSin Caddoans IN EAST CENTRAL OKLAHOMA
}

\author{
Robert L. Brooks
}

\begin{abstract}
The expansion of Arkansas River Basin Caddoans westward along the Canadian River remains an intriguing subject of study. This paper examines the presence of Caddoans living in the Ada vicinity, Pontotoc County, Oklahoma. The focus is on the Pickett Switch site excavated by Herbert Antle from 1930-1934. This paper examines the work of Herbert Antle, the history of his excavations as well as others at the Pickett Switch site, and describes a collection from the Pickett Switch site at the Sam Noble Oklahoma Museum of Natural History. Concluding comments continue to seek refinement in our understanding of the settlement practices of Arkansas River Basin Caddoans living on the western frontier.
\end{abstract}

\section{Introduction}

Brooks and Cox (2010) recently reported on the presence of Arkansas River Basin Caddoans living at the Allcorn Site (34ML1), a village on the Canadian River in central Oklahoma. Data on the Allcorn site were derived from materials excavated and collected in the 1920s and limited investigations conducted by the University of Oklahoma in 1947. Of particular note was a cemetery excavated by James Durham and others in 1927 that contained the remains of elites marked by the presence of earspools, high quality ceramics (Maxey Noded wares), and conch shell beads. An individual excavated by Virigina Watson during the 1947 University of Oklahoma fieldwork exhibited fronto-occipital cranial deformation such as that observed on individuals from Spiro and other Arkansas River Caddoan sites (Owsley 1989). Domestic goods excavated and collected at Allcorn included Woodward Plain ceramics, a variety of arrowpoints (Washitas, Haskells, Fresnos, Haskells, and Reeds among others) many of which were made from Florence A chert, and sandstone pipes with faceted surfaces more similar to those from eastern Oklahoma than the common elbow pipes of the Southern Plains (Brooks 2002). In discussing why these Arkansas River Caddoans were living so far from their homeland, an obvious question that arose was whether there were additional Caddoan settlements on the Canadian River between the Allcorn Site and Eufaula Mound in McIntosh County, some $170 \mathrm{~km}$ downstream on the Canadian River. An examination of the archaeological site files found no evidence Arkansas River Basin Caddoans living along the Canadian River between the Allcorn site in McClain County and the Eufaula Mound in McIntosh County. This was further collaboration for an earlier analysis of the Arkansas River basin Caddoan cultural landscape where the extreme distance of separation of the Nagle site in Oklahoma County and the Allcorn site in McClain County from the heartland was discussed (Brooks 2010).

Renewed examination of the intervening area of the Canadian River drainage between Allcorn and Eufaula Mound revealed hints of possible Caddoan sites in the Ada vicinity. The first item noted was an earspool reportedly found northwest of Ada on Springbrook Creek (Brooks 2011). Earspools are typically status markers for elites and their presence should be markers for a residential or ceremonial site occupied by Arkansas River Basin Caddoans. New information on this earspool suggests that the initial location was incorrect; a revised 
locale places it on Canadian Sandy Creek about $6.4 \mathrm{~km}$ south of the Canadian Sandy's juncture with the Canadian River and about $3.2 \mathrm{~km}$ north of Ada in Pontotoc County. The second item of interest is the work of H.R Antle in the 1930s on what he referred to as a "Caddoan Earth Lodge" site southwest of Ada on Canadian Sandy Creek. This location is thought to be that of the Pickett Switch site (34PN1) currently considered by archaeologists to represent a Plains Village settlement. Some of the material from Antle's investigations at Pickett Switch were recently found at Sam Noble Oklahoma Museum of Natural History and reexamined. Results of this analysis lend greater credibility to Antle's original interpretation of the site as a Caddoan settlement. There were also subsequent investigations at Pickett Switch by individuals from East Central College (now university) in the 1950s.

This paper presents a discussion of H. R. Antle and his work in east-central Oklahoma, a history of investigations at the Pickett Switch site by Antle and East Central College faculty, the results of an analysis of the Pickett Switch material in the Sam Noble Oklahoma Museum of Natural History collections, and offers some comments on occupation of the Ada area by Arkansas River Basin Caddoans.

\section{Herbert R. Antle}

Herbert R. Antle was a teacher in the Sulphur public schools where he taught High School math and science from the 1930s until World War II. It was during this period that he became interested in the local cultural and natural history. Antle collected aquatic samples from south-central Oklahoma eventually leading to a new species of clam shrimp being identified (Eulimnadia antlei; Mackin 1940). He also worked as a seasonal guide at Platt National Park in 1939-1940. Antle is best known for his anthropological analysis of southeastern removal tribes and archaeological investigations in east-central Oklahoma from 1930 to approximately 1942. In 1930 Antle started work at the Blay site (34PN1, Pickett Switch) southwest of Ada and worked there intermittently with the Boy Scouts until 1932 (Antle 1933). He cites lack of funds and proper equipment as reasons for abandoning the work. He corresponded with Joseph Thoburn of the Oklahoma Historical Society about Caddoan earthlodges and spent some time in 1933 studying archaeological techniques at the University of Oklahoma. There is no record of this year but it must have involved some association with Forrest Clements, Chair of the Department of Anthropology at the university. Following this educational experience, he returned to the Blay site where in September 1934 he renewed his excavations, excavating one structure (Antle 1934a-b). In March 1935, Antle salvaged materials from a sand quarry operation south of Ada. He excavated numerous refuse pits and portions of a structure (Antle 1935a). This site is thought to be a Plains Village settlement, although not documented in the archaeological site files. Later in 1935, Antle excavated at a rock shelter east of the Ada City Lake where he encountered Archaic and Woodland materials, including a copper ornament (Antle 1935b, 1942a). Sometime during the mid 1930s Antle turned his attention to the culture history of the Creek and Seminole tribes, publishing on the Tuskegee in Florida (Davis and Antle 1936), Seminole clan terminology (Antle 1936), and oral history (Antle 1942b). However, he continued to report on archaeological sites in the Pontotoc County area including a pictograph (Antle 1940) as well as presenting an overview of the prehistoric cultures of Oklahoma (Antle 1937,1938). While serving as a guide at Platt National

Park, he conducted investigations at a Plains Village site near Antelope Springs (Antle 1942c). This was the last documented archaeological study undertaken by Antle.

In 1942 he left his teaching position to enter military service. Following the war, Antle apparently found employment with Phillips Petroleum where he developed a process for the drying of ammonium nitrate in 1957. There is little information concerning Herbert Antle following his work at Phillips. 


\section{History of the Pickett Switch Site}

Pickett Switch (34PN1) was initially known as the Blay site, named after F. W. Blay, one of the original landowners. The subsequent label of Pickett Switch did not come about until sometime after Herbert R. Antle excavated the site in 1934 and perhaps after later work by East Central College in the 1950s. Pickett Switch refers to this being the switching stop for the Atchinson, Topeka, and Santa Fe Railroad.

The first investigation of Pickett Switch occurred in 1904 when Ike Gilmore, one of the initial landowners of the site dug into areas exposed by an Oklahoma Central Railroad line (later A, T\&SF). His brother, W. H. Meeks, and an Ada physician assisted him. They found piles of human bones and charcoal and at least one complete ceramic vessel (Antle n.d.). The Ada physician apparently dug the remains of nine individuals from one of the mounded areas during the same year.

According to James Shaeffer's original site form in 1956, B. G. Anderson of Ada found a number of small points in a cotton field on the site in 1921. Based on Antle's (1934a) article in the Tulsa World there were numerous "house mounds" present at Pickett Switch and that the site extended for close to a mile along Canadian Sandy Creek. In an earlier article in El Palacio he states that 10 mounds were present (Antle 1933). Antle undertook excavations at the site in December 1930 assisted by the Boy Scouts and continued these efforts until 1932. It is unclear how many of the 10 house mounds he excavated but the number certainly exceeds the two mounds he later claims to have opened (Antle 1934b:444). Antle encountered pottery, pipes, grinding stones, corn and acorns, and numerous human bones. He eventually abandoned the work for logistical reasons (Antle 1933). After a year of study and working with University of Oklahoma archaeologists that ended in 1933, Antle returned to the site in September 1934, excavating one structure. It is unknown whether this was one of the 10 house mounds described in his prior article in El Palacio or another mound. This structure was characterized as a mounded-over earthlodge with a hard packed floor that had been burned. No dimensions were given for the structure. The entrance to the structure was thought to be in the southwestern portion. In his article in the Tulsa World, Antle states that the houses were 30 feet in diameter.

He describes "caches" around the extremities of the mound that included charred acorns, pots of ear corn, mussel shell, stone and clay pipes, numerous vessels (some containing corn and acorns), celts, spearpoints, and flint objects (Antle 1934b). Antle characterized the ceramics as crude and heavy with little decoration. He contradicts this description in a later article when discussing a nearby Plains Village site as he states the ceramics from this site were considerably less well made than those from the Caddoan site five miles to the west. Antle notes that some of the ceramics from the Blay site were gourd-like jugs while others were open vessels. The one vessel illustrated in the Chronicles of Oklahoma article closely resembles that of a large water bottle (Figure 1). A distinguishing feature of the structure excavated by Antle was the presence of a large number of charred human remains, representing adults and children. The burned nature of the remains prompted Antle (1934a and 1934b) to suggest that they were the victims of a raid.

There is no further reference to Pickett Switch until November 1947 when David Wenner responds to a letter from Robert Bell concerning "the site over by Ada". David Wenner had previously been a student at the University of Oklahoma and in 1947 was a graduate student at the University of Chicago. Wenner's letter states that he had only visited the site once (in 1937) and made a surface collection. He confirms the location as being 100 yards northeast of Pickett Switch on the Santa Fe Railroad. Wenner mentions that there were some ten houses roughly 30 feet in diameter with burnt corn and logs found in the structures and further corroborates Antle's working there in the 1930s. There is a curious sentence in the letter about sending the ceramics to 
OU although it is unclear whether this sentence pertains to Pickett Switch or another site. Perhaps the most interesting item included with Wenner's letter is a series of artifact sketches on 3 x 5 note cards. These include a water bottle that appears to be same one Antle illustrated in his Chronicles of Oklahoma article with a caption that reads "somewhere at OU"; a large jar-shaped vessel, two bowls, one with a notation that it is red-slipped; and one card with a sketch of a willow-like pattern of incised designs (Figure 2). There are two additional note cards with sketches of stone or clay pipes. There is no reference in the letter to these sketches or any further information on how Wenner gained access to the material. But, all the sketches refer to the items as being from Pickett Switch.

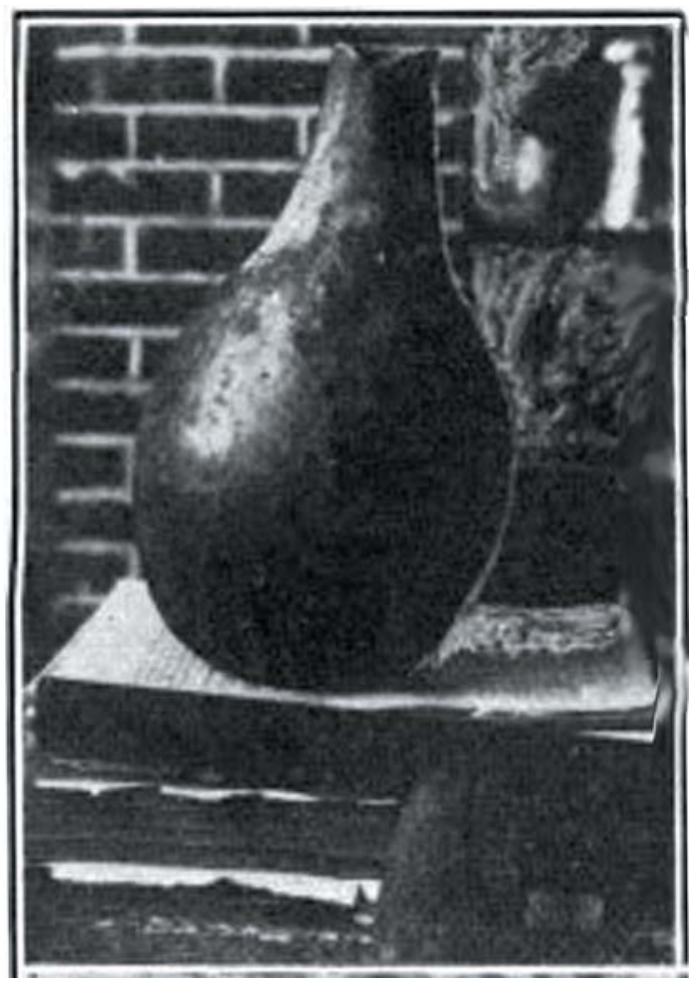

Figure 1. Water bottle from the Blay/Pickett Switch site depicted in Antle's 1934 report in the Chronicles of Oklahoma.

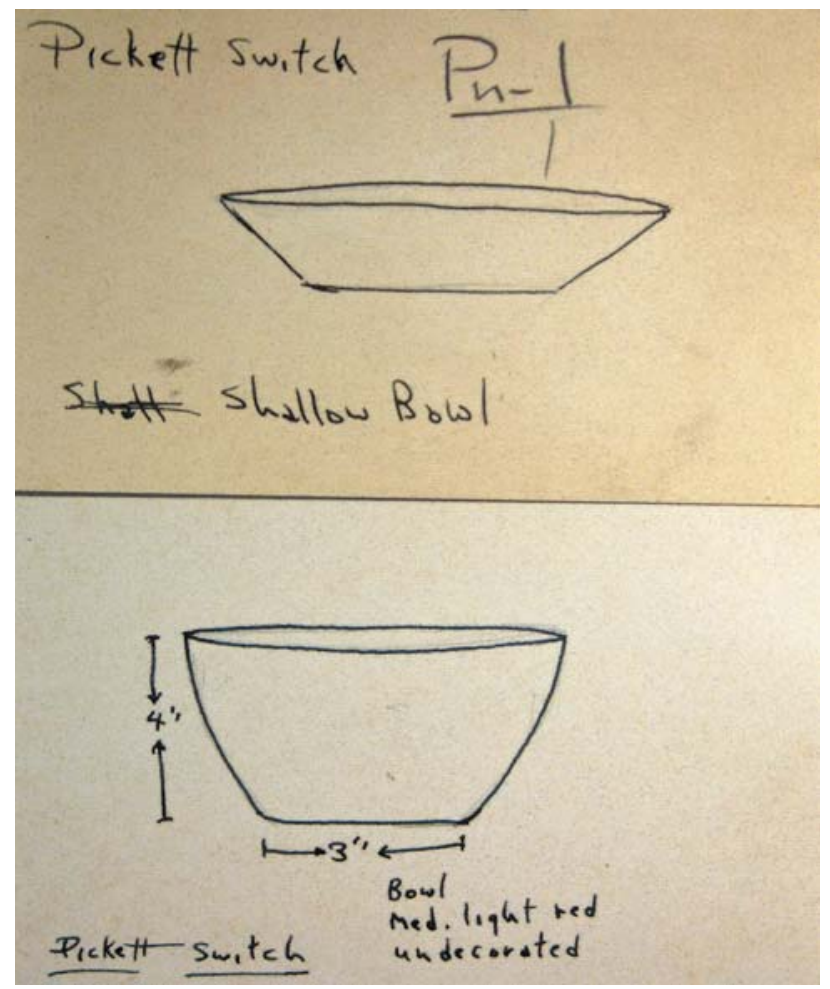

Figure 2. One of David Wenner's notecards with sketches of two bowls from Pickett Switch, probably from Antle's 1934 excavation.

Despite Bell's interest, Pickett Switch was not studied again until the 1950s. From November 1956 until February 1957, 0. C. Walz of the Sociology Department and Kenneth Campbell, Curator of the Art Museum at East Central College conducted excavations at the site (Schaeffer 1956, 1957a). Robert Bell, Oren Evans, and some of the graduate students at the University of Oklahoma visited the site during East Central's work and also provided assistance. Regrettably, there is no report or documentation on the results of this work. But, we can gain some knowledge of their investigations from Schaeffer's reports. Schaeffer (1957a:4) noted that the structures being studied by Walz and Campbell contained the remains of at least nine partially burned skeletons in one house. These remains were apparently scattered within the house but above the house floor. The house floor may be as much as $30 \mathrm{~cm}$ below the level where the human remains are present, suggesting two different events. There were few artifacts recovered during the East Central College excavations as Schaeffer notes only a bone digging tool, grinding basin, some pottery sherds, and few points, knives, and scrapers. In Schaeffer's 1957a report, he considers the sherds to have a gritty temper with distinctive sandpaper feel. In his earlier article, he states that the ceramics from the site do not resemble those from the Washita River groups 
(Schaeffer 1956). Schaeffer (1957a) mentions that he and Robert Bell have started going through the material from Antle's work, which had been donated to the University of Oklahoma. There is a large plan map of the Pickett Switch site in the Sam Noble Oklahoma Museum of Natural History collections. It is unclear whether this map of two structures and external features dates from Walz and Campbell's excavations or Antle's earlier work. Because two structures are depicted, it is thought that this plan view is from the later Walz and Campbell activity (Antle specifically mentions working on only one structure.). The plan view map illustrates two structures. Structure one is rectangular, 8 meters north-south by 6 meters east-west (Figure 3). The west wall of the structure exhibits a double post wall, perhaps reflecting a wall trench. There were four center posts noted and intra-mural bell-shaped pits. The second structure was roughly 28 meters in diameter and exhibited no evidence of support posts or internal features.

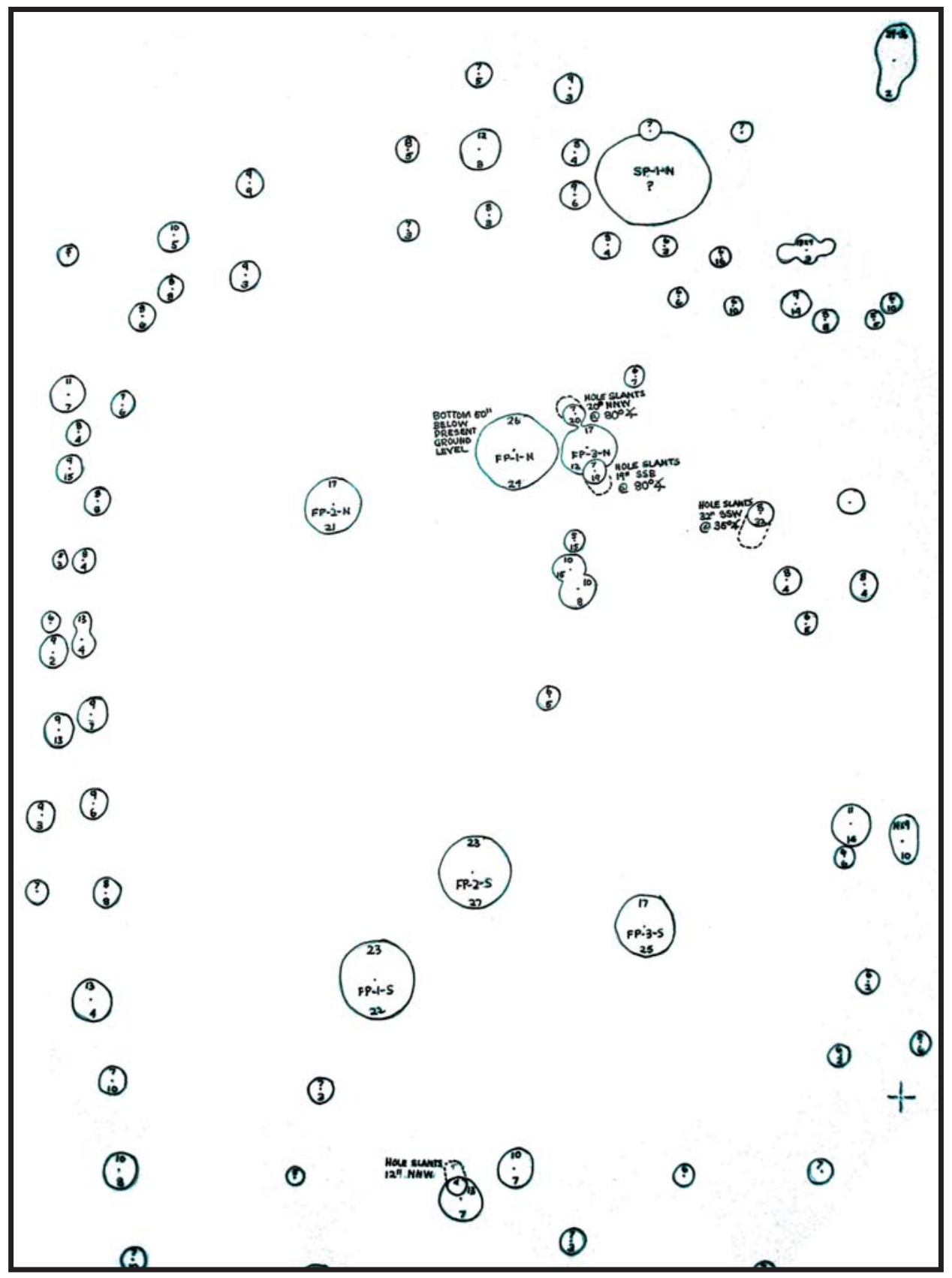

Figure 3. Plan map of the rectangular structure at Pickett Switch, probably from the 1956-1957 East Central College excavations. 
As discussed earlier, Antle's collection from the Pickett Switch site was donated to then Stovall Museum of Natural History at the University of Oklahoma in 1956. The inventory list provided for the Blay site has no information on complete vessels and there are no vessels from Pickett Switch in the collection, so it is unclear what happened to the ceramics sketched by David Wenner. The human remains excavated by Antle were given to an unidentified individual for analysis in 1934 and there is no information on their disposition. There is no history as to what happened to the artifacts and the human remains from East Central College's work in 1956/1957. A recent visit to East Central University as well as communications with the Department of Sociology and the Hallie Brown Ford Fine Arts Center found no trace of Walz and Campbell's investigations.

The most recent examination of Pickett Switch occurred in 1982 with a re-study of Pontotoc County archaeological sites by Kent Buehler of the Oklahoma Archeological Survey (Buehler 1982). Buehler found the site to be covered in dense grass although dark stains from either a house or refuse pit were found in a garden area. But, it is unclear if this is within the same area as that initially studied by Antle or later by Walz and Campbell.

\section{The Pickett Switch Site Locale}

There is some discrepancy concerning the location of the Pickett Switch site (34PN1). The location plotted on the state site file maps occurs on a terrace adjacent to the Canadian Sandy Creek (Figure 4). But, Antle describes the site as located on a sandy ridge that parallels the creek and extends for roughly a mile. Wenner in his letter to Robert Bell places the site about 100 meters northeast of the switch house on the Atchinson, Topeka, and Santa Fe Railroad. Thus, the site appears to be situated on the higher ridge rather than on the terrace adjacent to Canadian Sandy Creek. This setting is not unlike that of the Allcorn site where the village was on a high bluff overlooking the Canadian River rather than adjacent to the water source.

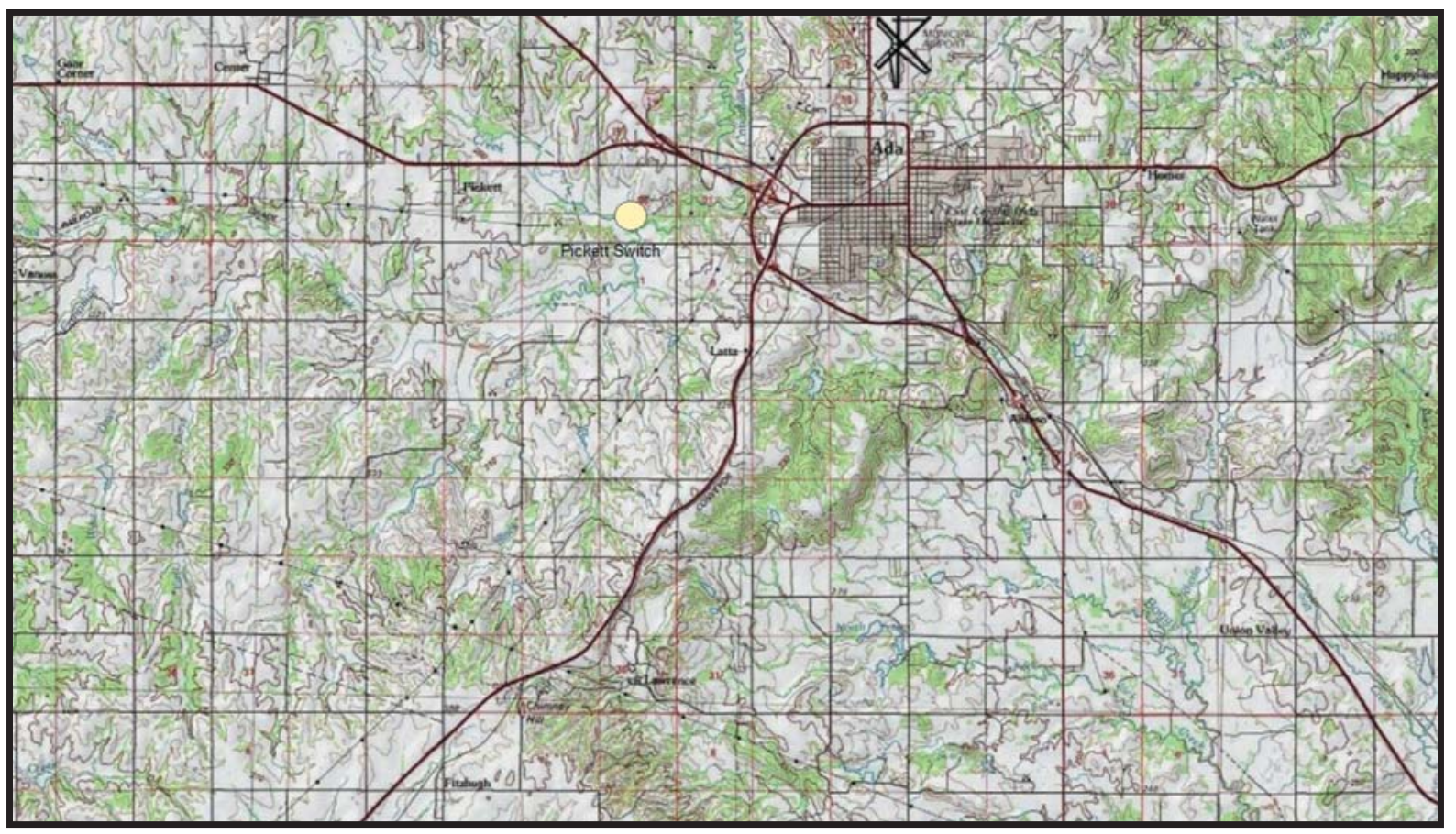

Figure 4. Location of the Pickett Switch site. 
The Pickett Switch site occurs in the Eastern Sandstone Cuesta Plains region (Johnson 2006). This area, southwest of Ada consists of some 30 meters of conglomerate, limestone, coarse sandstone, and light-colored sandstone of the late Pennsylvanian Ada Formation (Miser 1934; Cederstrand 1996). Pickett Switch is also within the Cross Timbers eco-system (Woods et al. 2005). This is a mix of savanna, woodlands, and prairie that separates the eastern forests from the western grasslands. Wooded areas are principally dominated by post oak and blackjack oak in the uplands with oaks, hickories, walnut, pecan, and cottonwood occupying the alluvial valleys. Grasses in the Cross Timbers consist primarily of big and little bluestem and Indian grass. These forest and prairie flora are interspersed in the savanna areas. Fauna in the area prehistorically would have included bison, white-tailed deer, antelope, elk, black bear, gray wolf, bobcat, beaver, raccoon, opossum, cotton-tail and jackrabbit, and fox squirrel. Dominant bird species included wild turkey, quail, waterfowl, and raptors (hawks and owls). Streams in the region range from shallow with a gravel or cobble substrate to larger streams and rivers that have wide floodplains and are frequently sand-choked. Major fish species are smallmouth buffalo, river carpsucker, redhorse, channel and flathead catfish, bass, and sunfish. Soils in the vicinity of Pickett-Switch are comprised of the Talpa series of shallow, well-drained soils in the uplands and the Port series of deep, welldrained soils in the valley of the Canadian Sandy.

\section{Artifacts from Pickett Switch}

There was some confusion regarding materials from Antle's investigations at the Pickett Switch site curated at the Sam Noble Oklahoma Museum of Natural History. There were a number of boxes labeled as PN/0 and designated as either the Blay site or as the Antle collection. There is also an inventory list of Antle's material from Blay or Pickett Switch. However, Antle's materials were not directly donated to the museum. Antle's collection was originally given to Platt National Park (now the Chickasaw National Recreation Area). Dr. E. Holland of the National Park Service subsequently donated these materials to what was then Stovall Museum of Natural History in the summer of 1956. It is unclear if this is all of Antle's material from his 1930/1934 excavations or only a partial inventory. There was also no documentation on the materials from Antle. As Antle collected or dug at a number of sites, whether the items designated as being from the Blay/Pickett Switch site are actually from this location remains questionable. There is no foolproof means of determining the provenance of Antle's PN/0 artifacts. Here, a rather tenuous thread of inference was used to determine which of these items originated with his work at Blay/Pickett Switch. It is well documented that Antle as well as Walz and Campbell encountered burned structures in their work at the site. Thus, artifacts expressing some degree of burning or exposure to high heat were considered to be from Antle's work at the site. This includes numerous ceramics artifacts, ground stone, some chipped stone items, burned bone, and charred plant remains (corn kernels and cupules). There were additional items in the PN/0 collection accessioned as being from the Blay/Pickett Switch that are not included here, principally because they are unburned and they also do not fit with the collection that is burned.

Some 343 ceramics are thought to be from Antle's excavations at Pickett Switch, many of which exhibit some evidence of burning (Figure 5). The high-heat, comparable to re-firing, created surface cracking and many sherds exhibit a bright orange color. Some sherds also have silica froth on their surfaces. There are 255 body sherds that are plain-surfaced, shell-tempered wares (Figure 6), with a smaller number that are limestone-tempered (1), or grit-tempered (22). Seventeen body sherds that are cord-impressed with 10 that are limestone-tempered and seven that are shell-tempered. An additional 15 body sherds could not be identified due to extreme exposure to high temperatures. Vessel bases are flat, small, and round. They are very similar to those documented on a large jar-like vessel from the Allcorn site (Figure 7). Of the 14 basal sherds, 13 are plain-surfaced and one is cord-impressed. Seven of the plain-surfaced bases are shell-tempered, five are grit- 
tempered, and one is limestone-tempered. The one cord-impressed basal sherd is limestone-tempered. There are 21 rim undecorated rims sherds. Nineteen of these are plain-surfaced with 15 being shell-tempered, three limestone-tempered, and one grit-tempered. One additional rim is cord-impressed and shell-tempered. There is also one rim sherd/pipe fragment of shell-temper. Most of the rims exhibit strait walls (two are everted) with flat lips. There are eight decorated/modified sherds. One is a grit-tempered rim sherd with a dendritic pattern of incising on the wall below the rim (Figure 8). There is one shell-tempered sherd with two nodes on the neck of the vessel area and one with a strap-handle. There is also one shell-tempered sherd with a red slip (Figure 8) although it is suspected that others may have been slipped but masked by the high temperatures in the structure (Figure 9). There are also four sherds that appear to be of southwestern origin. While these sherds would normally be excluded, they are included here because at least one them exhibits evidence of burning. The four southwestern sherds are a black-on-white ware, a corrugated gray ware, a plain-surfaced gray ware, and a plain-surfaced gray ware rim sherd (Figure 10). It remains questionable whether these four sherds are from Antle's work at Pickett Switch. If so, they are some of the first examples of southwestern material found at an Arkansas River Basin Caddoan site.

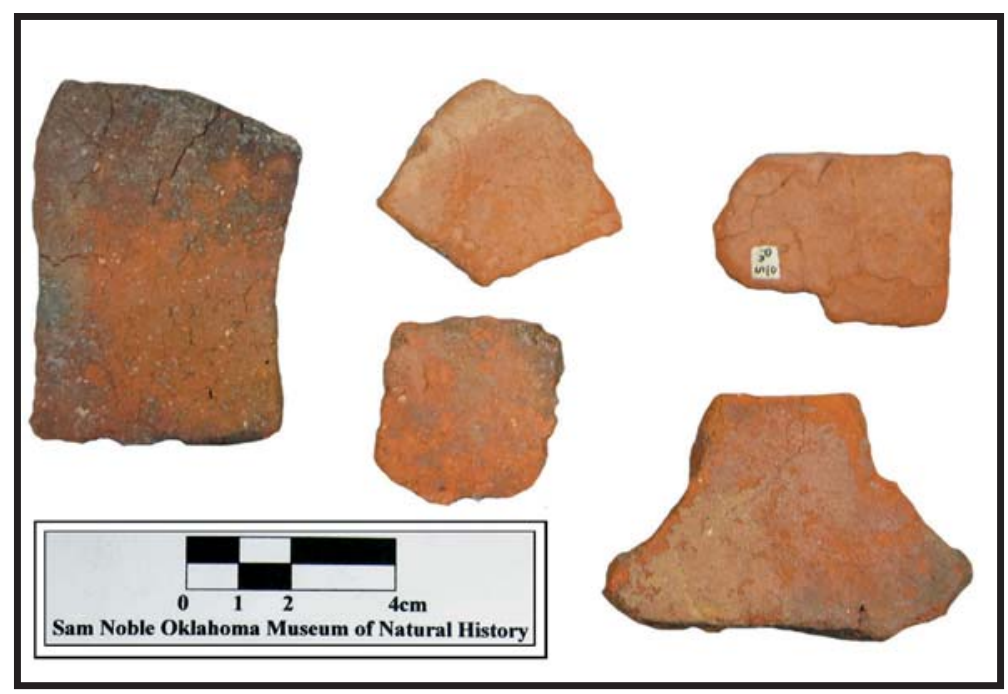

Figure 5. Ceramics from Pickett Switch illustrating surface cracking from burning as well as color change.

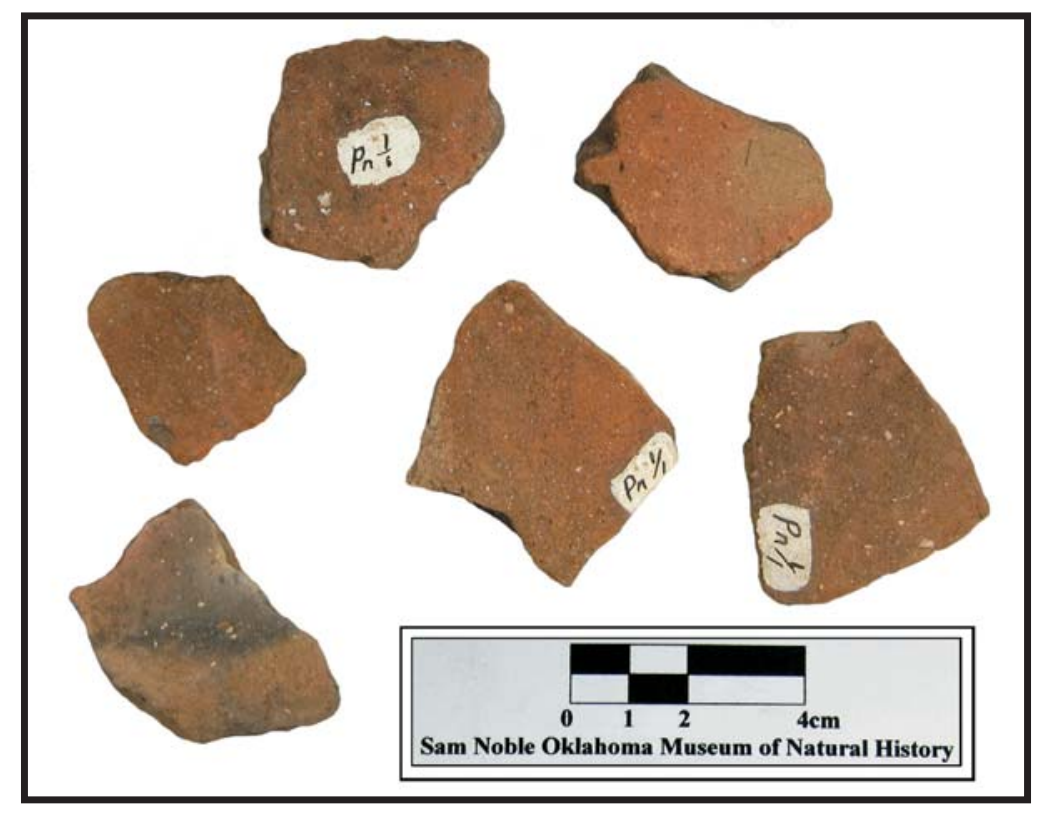

Figure 6. Woodward Plain specimens from the Antle collection. 


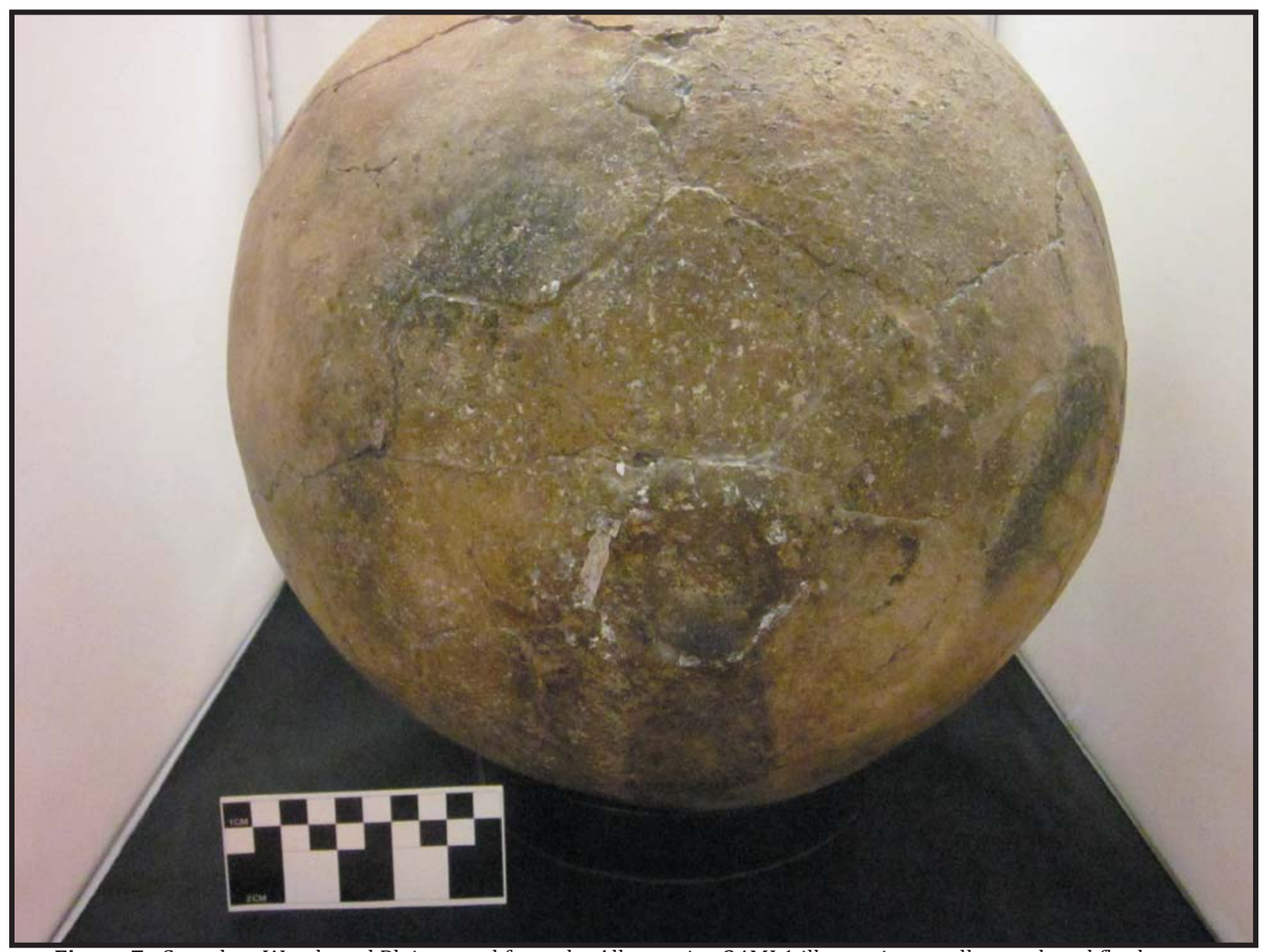

Figure 7. Complete Woodward Plain vessel from the Allcorn site, 34ML1 illustrating small, round, and flat base.

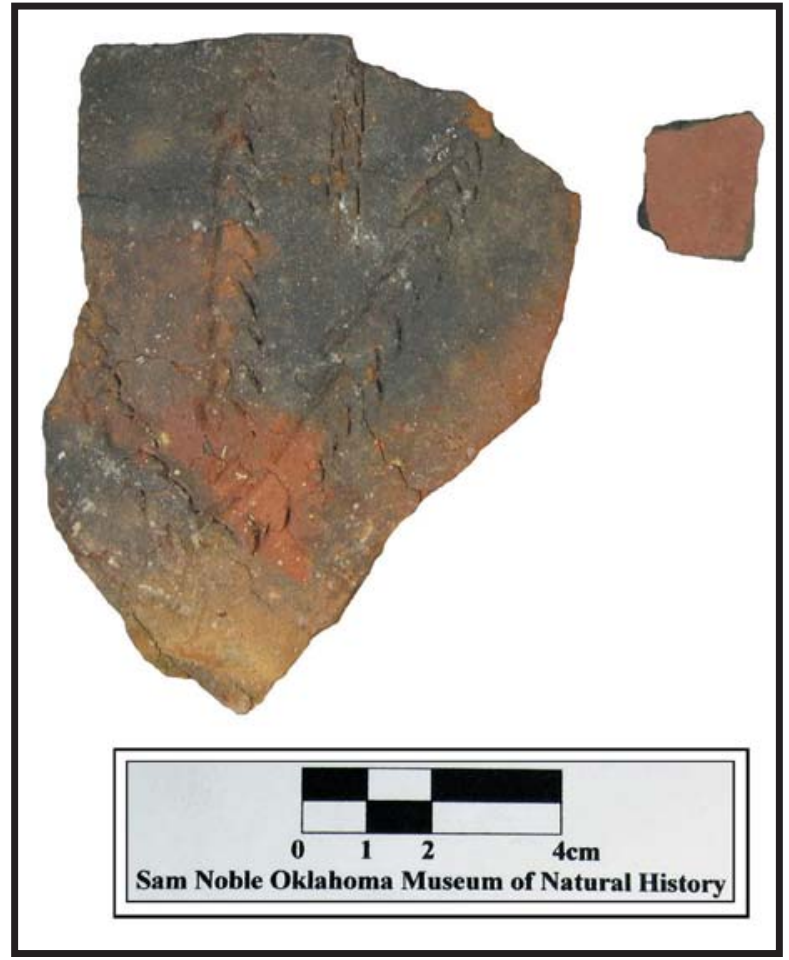

Figure 8. Incised dendritic pattern on rim sherd from Pickett Switch. 


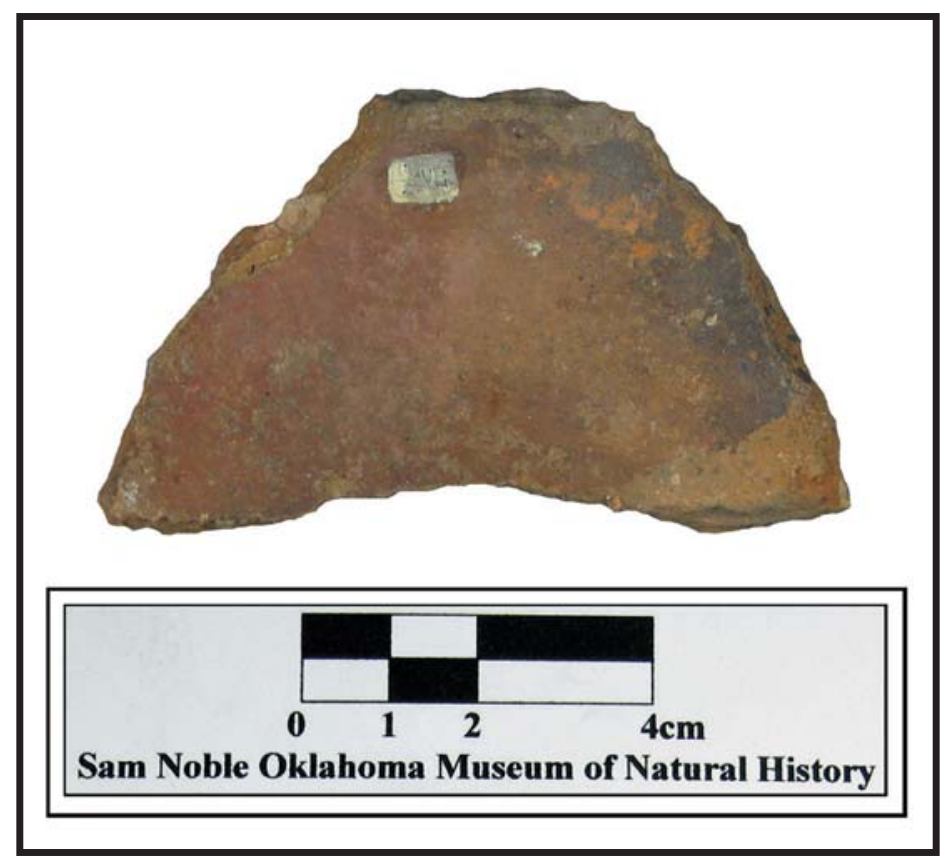

Figure 9. Badly burned red-slipped sherd from Pickett Switch.

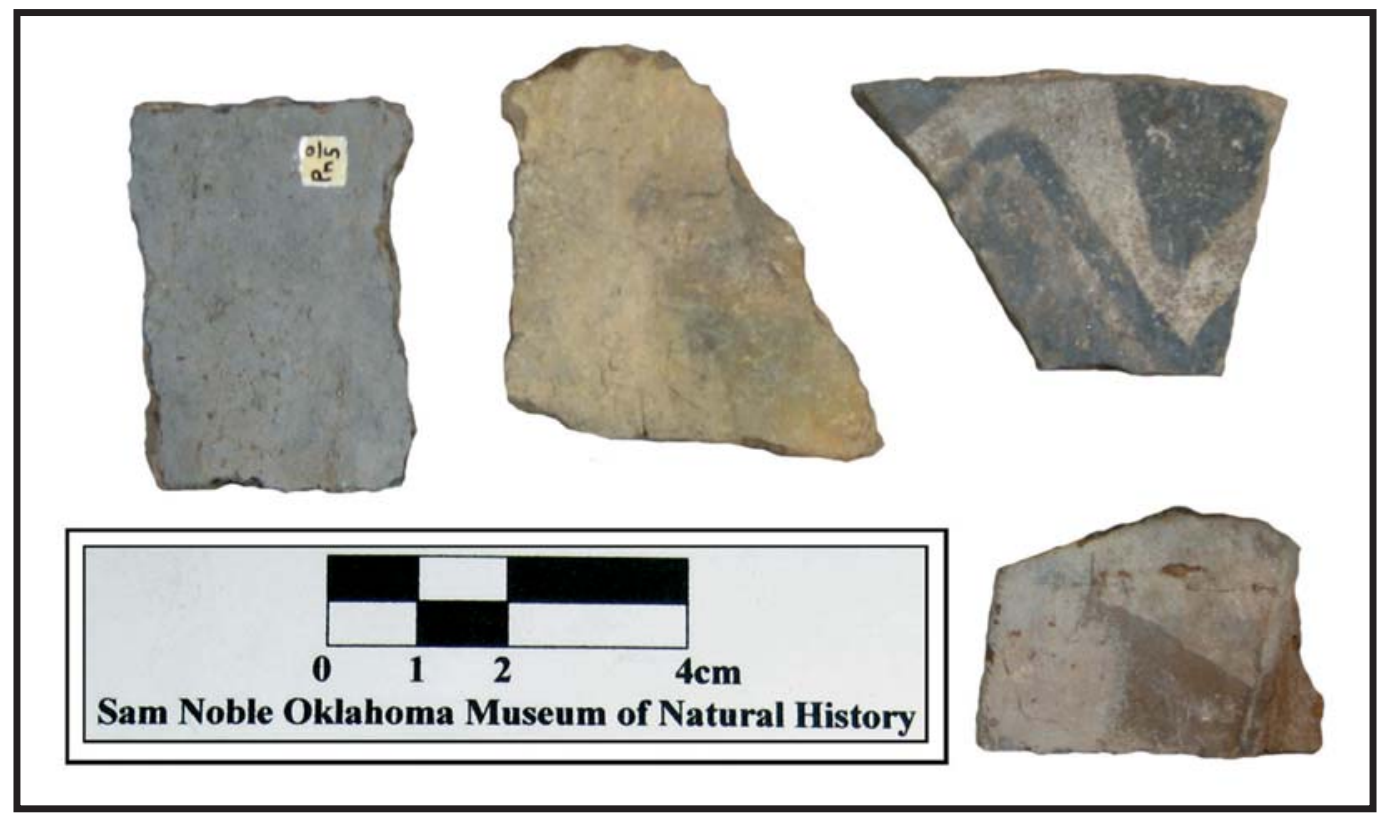

Figure 10. Gray wares possibly from Pickett Switch. Dark clouding on the sherds is from burning.

Ten pieces of ground stone are thought to be from Antle's work at Blay/Pickett-Switch due to the presence of burning. These include three celts: one fragmentary specimen of quartzite, one of diorite, and one made of hematite. The latter specimen might also be a gorget due to its flat, rather thin cross-section (Figure 11). There is a gorget made of hematite as well (Figure 11). Two manos are thought to be from the excavated structure. One is oval and similar to those found at Arkansas River Basin Caddoan as well as Plains Village sites whereas the other specimen is circular in shape and distinguished by an area of hematite staining on one grinding surface (Figure 12). This mano is probably associated with a flat segment of shale with a comparable area of hematite staining (Figure 13). Antle's excavation of the structure also recovered one highly burned hammerstone. The remaining two ground stone items are a small sandstone abrader and what may be a fragment of an earspool manufactured from sandstone. 


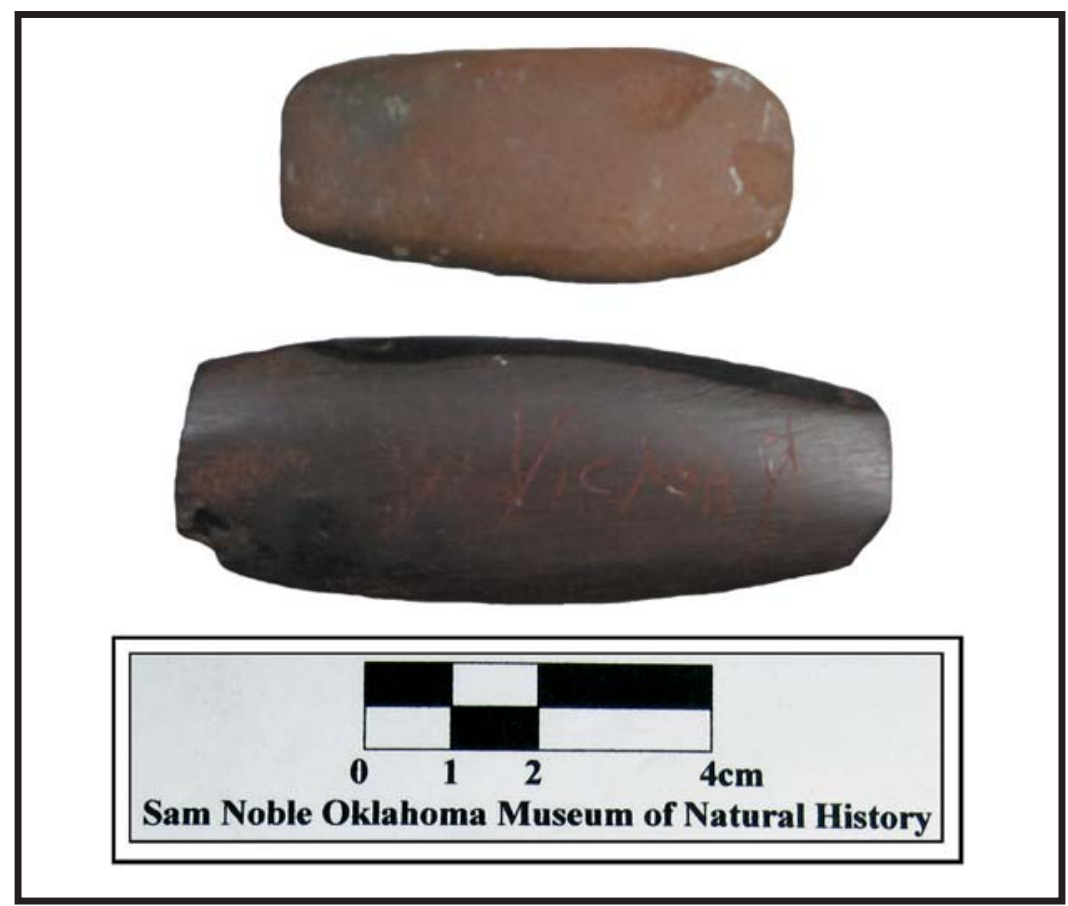

Figure 11. Gorgets from Antle's excavations at Pickett Switch.

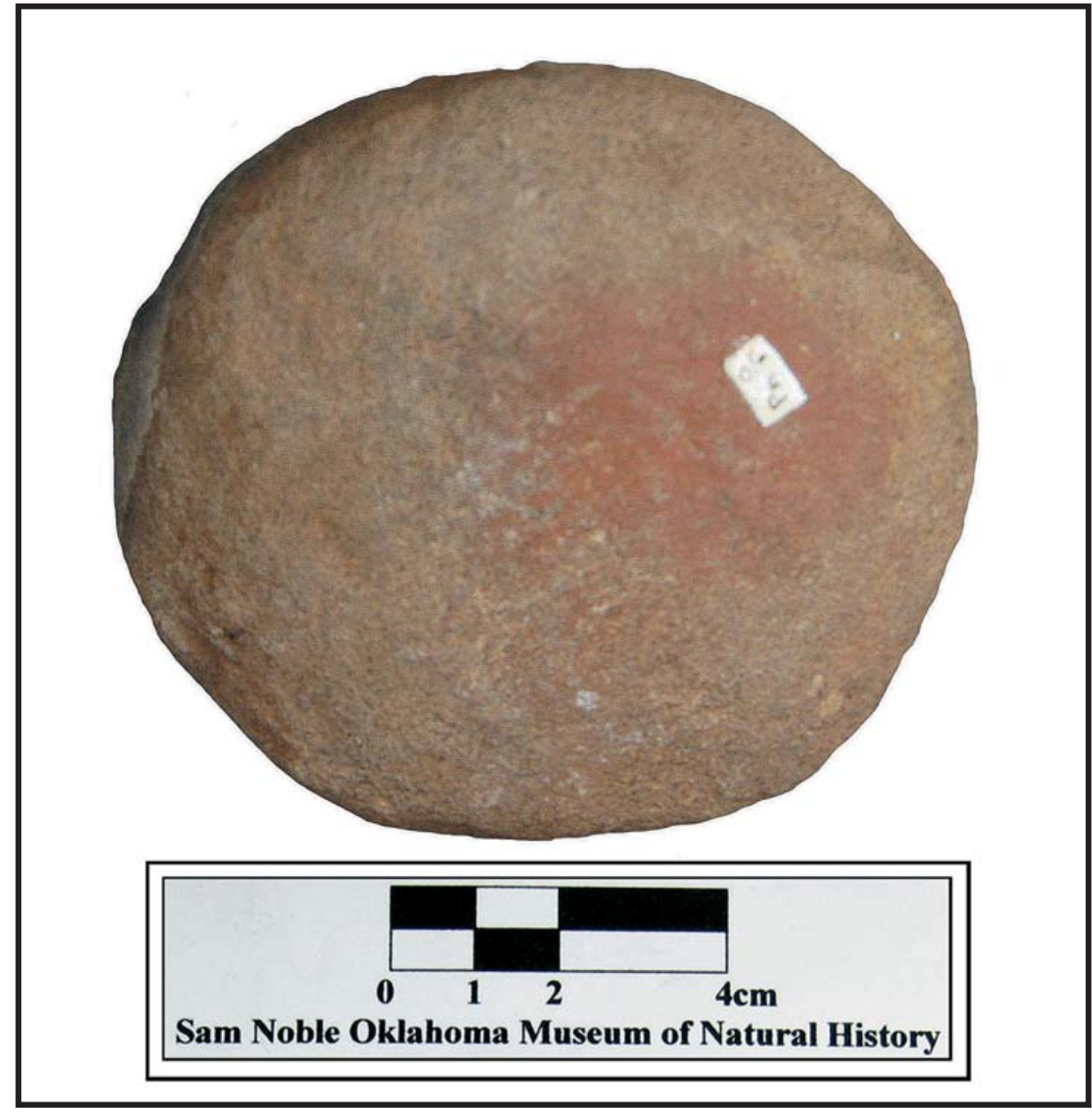

Figure 12. Mano with hematite staining. 


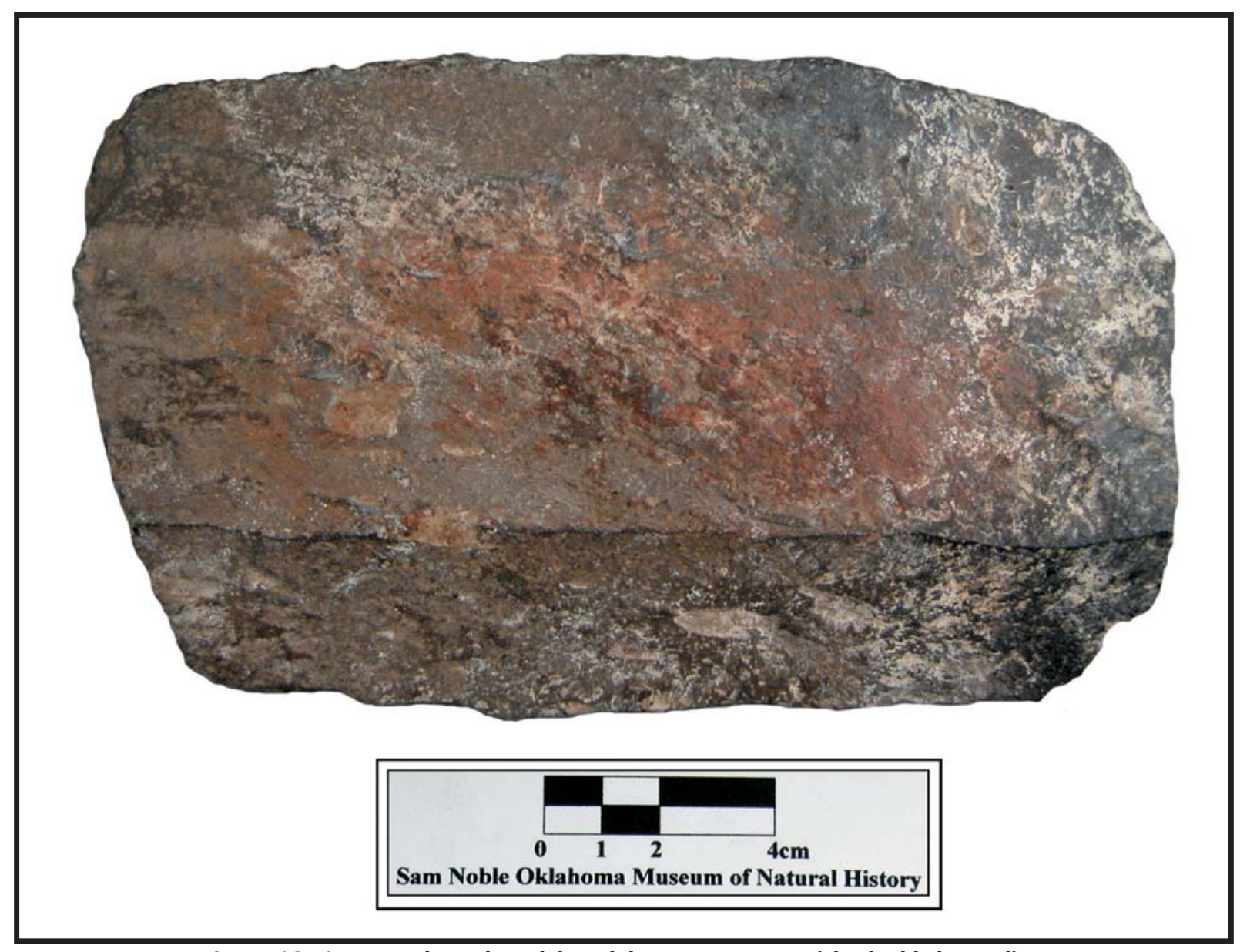

Figure 13. Associated grinding slab with hematite staining (also highly burned).

There are 124 items of chipped stone in the Antle collection accessioned as being from the Blay/Pickett Switch site. But, it is questionable that all of these items are from Antle's excavations. Some of the specimens have evidence of exposure to fire or have charcoal staining. Others though, are less convincing. There are seven Gary points that are very likely from Pickett Switch. This is somewhat confirmed by Schaeffer's (1956) note that a Gary point was excavated from a structure at Pickett-Switch during Walz and Campbell's work in 19561957. The five square-stemmed and four corner-notched dart points are questionable as to their provenance. But, one stemmed point and one corner-notched fragment are burned and lends some credibility to their being from Antle's excavations. This provenance issue also holds true of one side-notched dart point, one with a concave base, and a fragment of a Dalton point (unless a curated item). One Reed-like and one Bonham style arrowpoint would fit with what we know of an Arkansas River Basin Caddoan occupation of the site. But, the two Fresno arrowpoints that are included with the Pickett-Switch material are somewhat suspect. Most of the bifaces could be from Pickett-Switch as they exhibit some degree of heat exposure. This includes 39 bifaces and bifaces fragments, many manufactured of the nearby Frisco chert (although there is one fragment of Boone chert). Of particular note are 10 bifaces of Alibates agatized dolomite. Six of these are fragmentary but represent large, thin bifaces that are comparable in size to some of the ceremonial blades found at Spiro (Figure 14; Brown 1996). There are also six bifaces of Frisco chert that appear to represent a cache due to their similarity in size and shape (Figure 15). There is one additional category of chipped stone worthy of note: two double bitted axes made of Alibates agatized dolomite (Figure 16). These represent one of the very few cases of double-bitted axes of non-eastern Oklahoma tool stone. The remaining specimens include eight unifacial scrapers and 53 flakes, chunks, and cobble fragments of Frisco chert, quartzite, and unidentified cherts. 


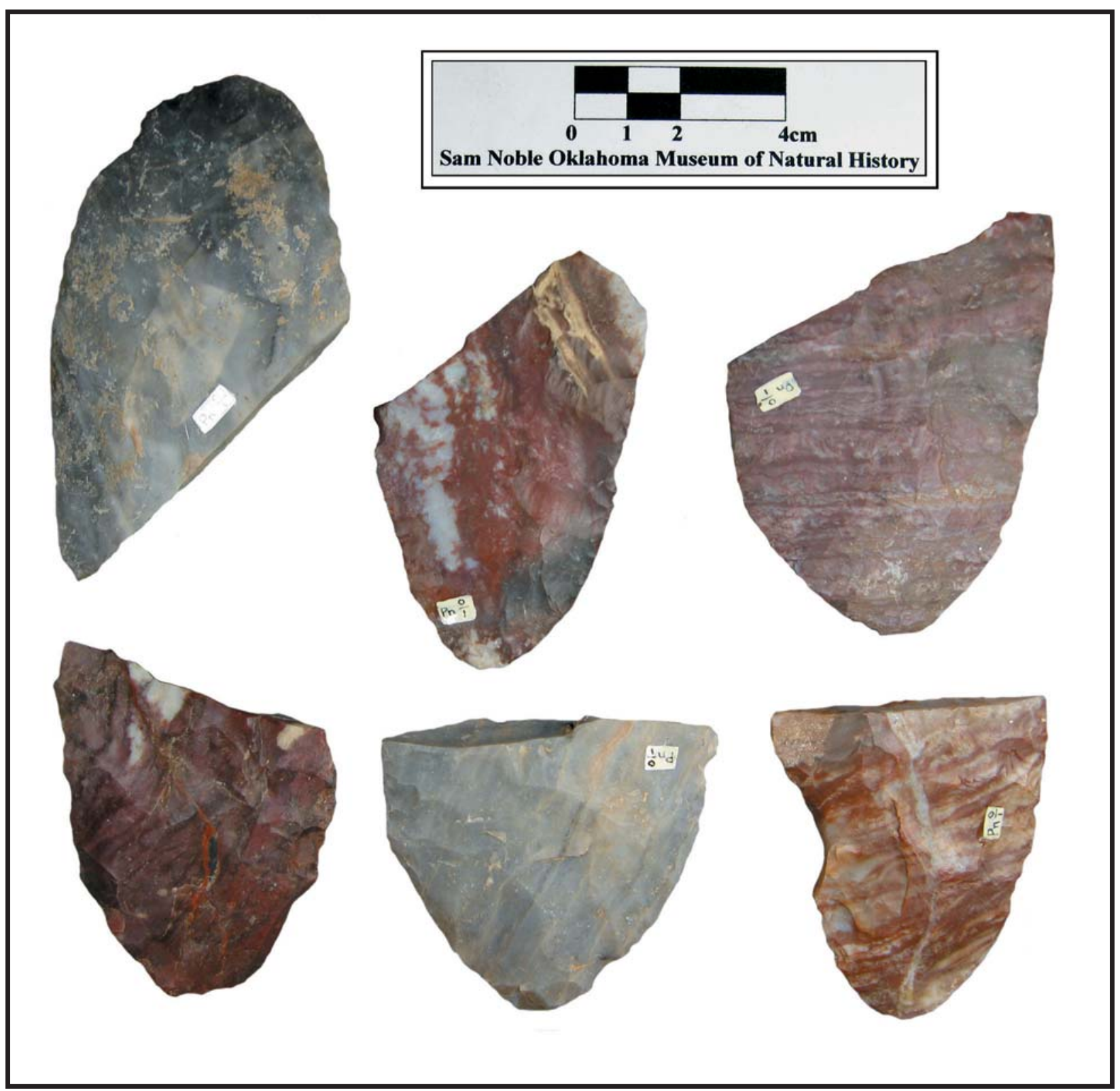

Figure 14. Large Alibates agatized dolomite bifaces from the Antle collection. 


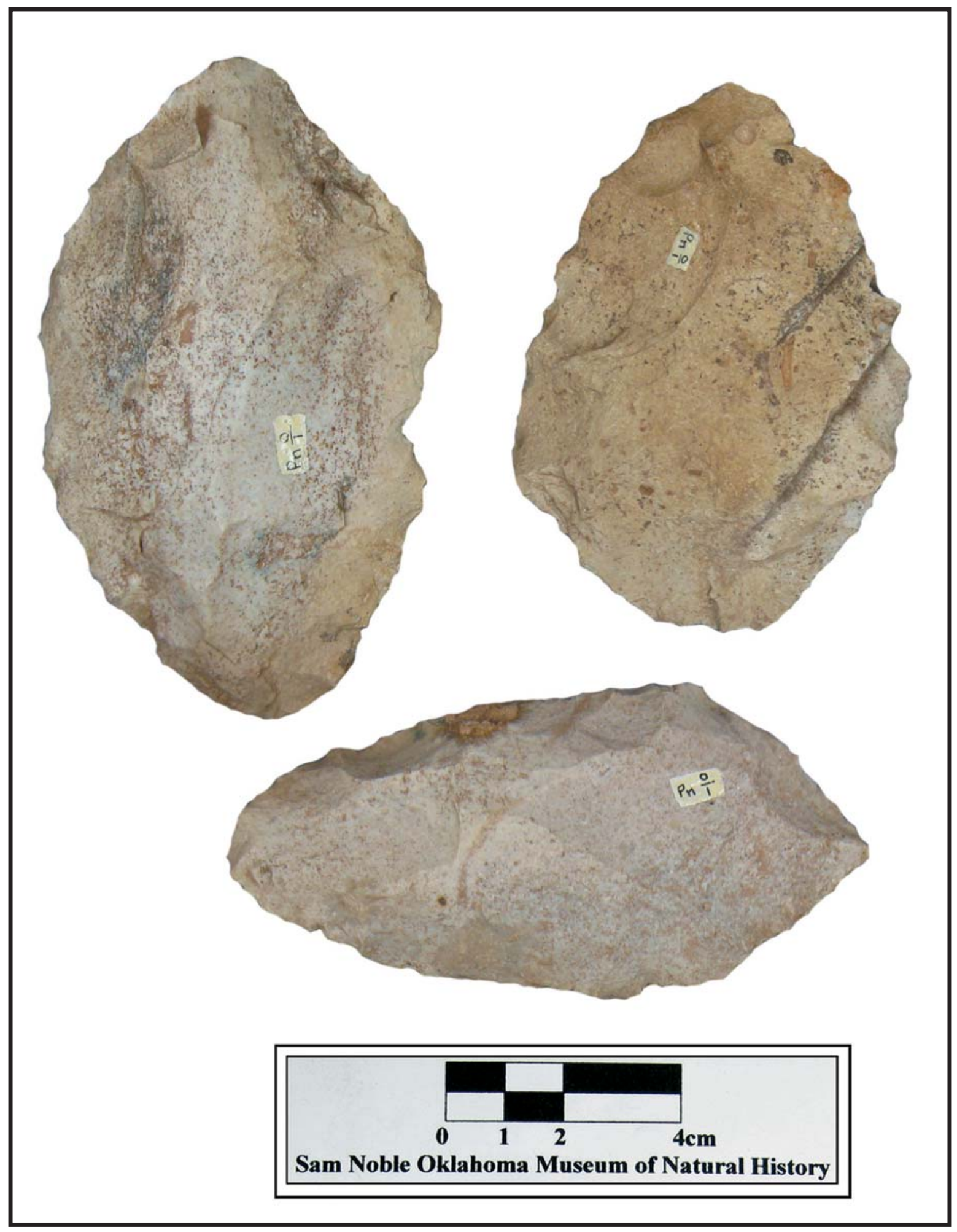

Figure 15. Frisco chert bifaces thought to represent a cache from Pickett Switch. 


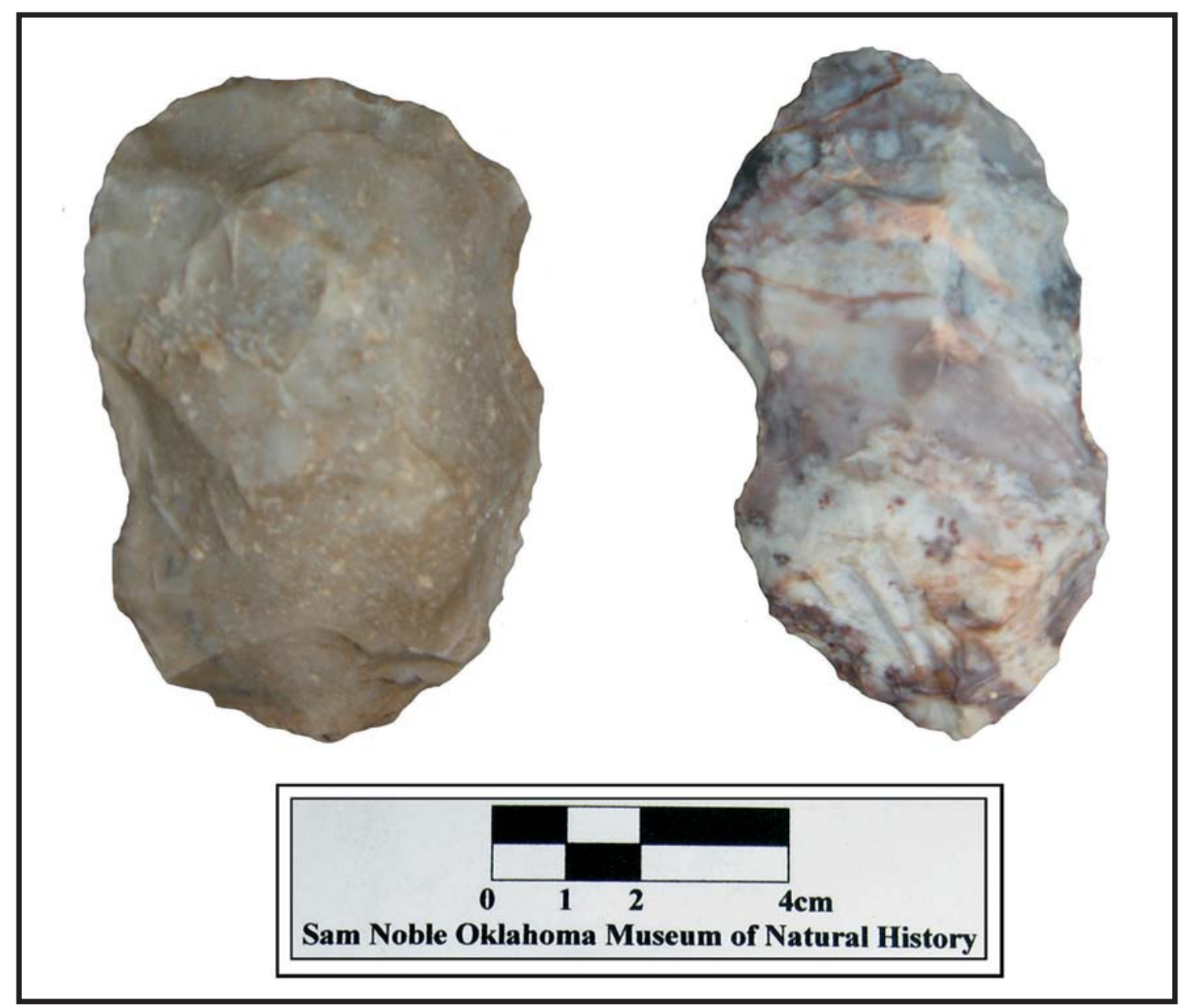

Figure 16. Double-bitted axes from Pickett Switch. Specimen on right is made of Alibates agatized dolomite.

Faunal remains (13) are very infrequent at Pickett-Switch. Eleven of the bone fragments represent the remains of white-tailed deer including a highly burned antler segment and two specimens that are too calcined to identify. Charred plant materials are restricted to corn cupules and kernels. There are 15 fragments of burned clay (daub) in the museum collection. Three mineral specimens are believed to be from the structure Antle excavated. One is a green crystalline substance residing on a granite base material from the Arbuckle Mountains (Figure 17). Neil Sunneson of the Oklahoma Geological Survey identified this substance as epidote. Epidote could be ground/pulverized to create a green pigment. There is also a moderate-sized piece of hematite present. The remaining specimen is burned but could be a tabular segment of mica. Another possibility might be a marble-like material. Both the mica and the marble-like material are non-local, probably originating in the Ouachita or Appalachian mountain regions. 


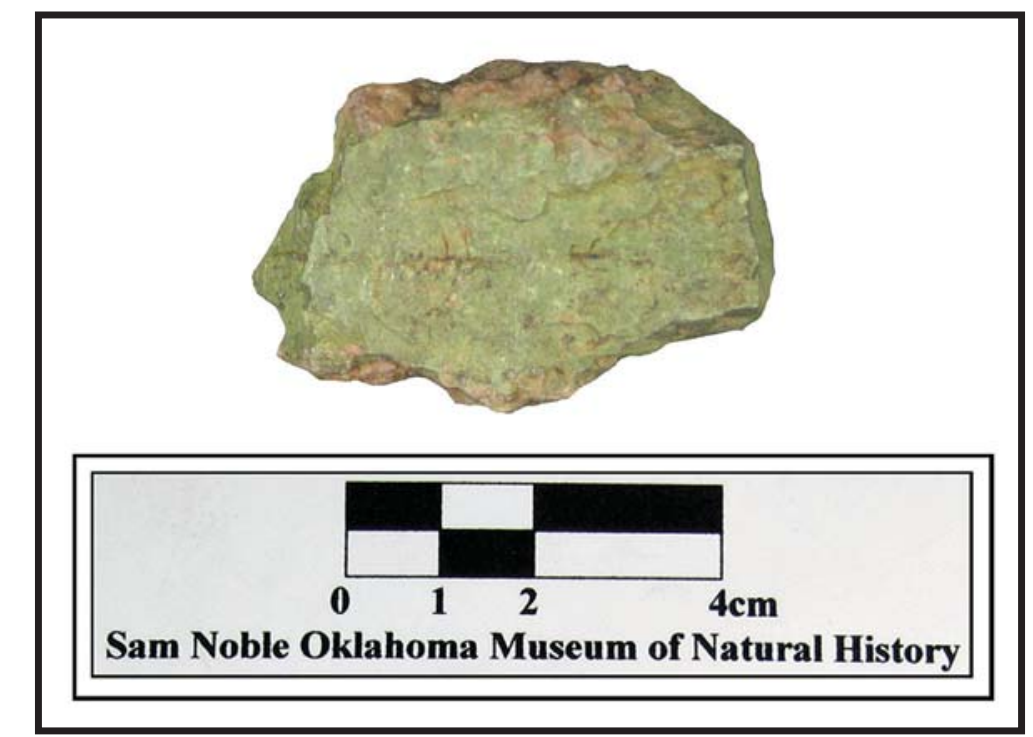

Figure 17. Specimen of epidote thought to be from Antle's excavation at 34PN1.

\section{Chronology of Pickett Switch}

A sample of the charred corn kernels from Antle's excavations at the Pickett Switch site was submitted to Beta Analytic for ams dating. Two runs were accomplished from this sample. The first run (Beta-299722) yielded a measured radiocarbon age of $400 \pm 30 \mathrm{BP}$ with a $13 \mathrm{C} / 12 \mathrm{C}$ ratio of $-9.2 \mathrm{o} / \mathrm{oo}$. The two-sigma calibration on this run was A.D. 1280 to A.D. 1320. The second run (Beta-299723) yielded a measured radiocarbon age of $390 \pm 30 \mathrm{BP}$ with a $13 \mathrm{C} / 12 \mathrm{C}$ ratio of -8.5 o/oo. The two-sigma calibration for this run was A.D. 1280-A.D. 1320 . These dates are consistent with the artifact assemblage recovered- especially if the vessel forms that Wenner illustrated are from the site. This places Pickett Switch in the same relative time frame as the Nagle and Allcorn sites (circa A.D. 1200 or slightly later).

\section{The Ada Earspool}

As reported previously, the Ada earspool was thought to originate on Springbrook Creek northwest of Ada (Brooks 2011). While the location was vetted by oral history, further scrutiny found this location to be in error. Additional questioning of the son of the collector revealed that the earspool was actually found on Canadian Sandy Creek about $3.2 \mathrm{~km}$ north of Ada. The earspool is on the same drainage as the Pickett Switch site but closer to the Canadian Sandy's confluence with the Canadian River. This area has undergone extensive commercial and residential development and the site where the earspool was found has undoubtedly been destroyed. One interesting aspect of Antle's work at Pickett Switch is that despite finding numerous individuals and ceramic vessels that appear to be of Arkansas River Basin Caddoan origin, he found no exotic materials such as earspools or shell such as that encountered at the Nagle (340K4; Shaeffer 1957b) or Allcorn (34ML1; Brooks and Cox 2010) sites. Perhaps there were no elites in residence at Pickett Switch but the Ada earspool demonstrates that were Caddoan elites living somewhere on the Canadian Sandy, assuming that our most recent information is correct. 


\section{Concluding Comments}

Material recovered during H. R. Antle's work at the Pickett Switch site provides some support for the argument that Arkansas River Basin Caddoans were living in the Ada vicinity on Canadian Sandy Creek. Foremost among these items is the image of what appears to be large water bottle in Antle's (1934b) Chronicles of Oklahoma article. The vessel could easily be found among ceramic assemblages at Harlan, Norman, or Spiro. Other ceramics from the site, although distorted by intense heat, can be identified as Woodward Plain, a shelltempered ware common in eastern Oklahoma during Caddoan times. There are also red slipped ceramics that are too fragmentary and burned to allow identification of the type variety. One sherd with an incised, dendritic pattern is thought to originate from the Red River Valley Caddo although it is not a recognized variety. The hematite gorget, large blades/bifaces, and double-bitted axes also point to an eastern Oklahoma origin. If the epidote, hematite, and mica/marble found in the Pickett Switch collection are truly from the site, these would be logical items for Arkansas River Basin Caddoans to have in their possession.

The sketches of a ceramic water bottle, jar and two bowls included in David Wenner's letter are labeled as being from Pickett Switch. These sketches appear to represent Caddoan wares. The "willow pattern" sketched on one notecard is similar to the specimen in the Antle collection although it also holds some differences. This may be the same sherd or perhaps a second specimen from the same vessel. The obvious problem is that these objects are not in the Antle collection and cannot be verified except perhaps for the water bottle that is illustrated in the Chronicles article.

Despite this evidence, questions remain as to whether this is an Arkansas River Basin Caddoan site. None of the human remains excavated by Antle or Walz and Campbell have been rediscovered; the characteristics of these people are unknown. If any of them exhibited fronto-occipatal cranial deformation, this would represent compelling evidence for the presence of Arkansas River Basin Caddoan elites. The presence of status markers such as earspools or conch shell would be equally convincing. But, since these data are not available, conclusive evidence as to the origins of the people living at Pickett Switch remains unresolved. But, it can be substantiated that Pickett Switch bears few similarities to Plains Village sites such as those found in the Washita River phase (Brooks 1987).

If Pickett Switch is an Arkansas River Basin Caddoan residential site, it is different from the Allcorn site in that it is not located on the Canadian River proper. The nature and function of the structures at Pickett Switch also remains unclear. Antle reports them as being 30 feet $(9 \mathrm{~m})$ in diameter with an apparent waddle and daub construction (described as earthlodges). But, the undated plan map thought to originate with the work by Eastern State College portrays a rectangular structure as well as one that is possibly circular. The structures appear to function as domestic residences with the deceased individuals present representing an intrusive event. But, there are a couple of cryptic comments by Antle that make the structures appear to look much like charnel houses. Regrettably, without a modern examination of a structure from Pickett Switch, this dilemma will not be resolved.

The previously discussed earspool is now thought to originate north of Ada on the Canadian Sandy. This item also comes from the tributary stream rather than the Canadian River proper. No studies have been conducted of the Canadian River in the Ada vicinity, especially where the Canadian Sandy Creek joins with the Canadian River. Such survey efforts might reveal the presence of prominent residential sites of Arkansas River Basin Caddoan origin. 
What were Arkansas River Basin Caddoans doing in the Ada vicinity? It has been argued that the expansion of Caddoans beyond their eastern Oklahoma homeland represented an attempt to spread a political/ religious message (Brooks and Cox 2010). The Allcorn site on the Canadian River and the Nagle site on the North Canadian River represent what is apparently the western extent of this attempt to spread their belief system. In this type of expansionism, there are frequently intervening outposts or stations from which groups depart to the frontier. Pickett Switch, on a major tributary of the Canadian River, may represent one of these residential outposts. That evidence at Pickett Switch that suggests violence is also not surprising. One of the elite elders of the Nagle site population had arrowpoints in his thoracic cavity and was scalped (Brues 1957). There are additional questions concerning the Allcorn residents and whether Plains Villagers replaced them in a violent or non-violent fashion (Brooks and Cox 2010). Basically, we are left with more questions to answer than those we have resolved. It is evident that more work is merited in the Ada area to examine the potential for Arkansas River Basin Caddoans.

\section{Acknowledgements}

I want to express my gratitude to Liz Leith of the Sam Noble Oklahoma Museum of Natural History in helping me track down the Pickett Switch materials at the museum, especially the large plan map and David Wenner's letter and note cards to Robert Bell. The museum also graciously permitted a sample of corn from the site to be radiocarbon dated.

Antle, H. R.

n.d. The Mounds of Pontotoc. Unpublished draft manuscript, Thoburn Papers (Box 2, Folder 13), Research Center, Oklahoma History Center.

1933 The Mounds of Pontotoc. El Palacio XXXIV(3-4): 17-23.

1934a Sooner Settlement: Earliest Habitation Was Wiped Out by Fire, Famine, Pestilence, or Hostile Tribes. Tulsa World September 3, 1934.

1934b Excavation of a Caddoan Earthlodge. Chronicles of Oklahoma 12:444-447.

1935a Report of an Archaeological Site. Chronicles of Oklahoma 13:191-195.

1935b A Bluff Shelter in East Central Oklahoma. Chronicles of Oklahoma 13:313-315.

1936 Interpretations of Seminole Clan Relationship Terms. Chronicles of Oklahoma 14: 343-348.

1937 Archaeological Aspects of Pontotoc County. Proceedings of the Oklahoma Academy of Sciences 17.

1938 A Proposed Nomenclature for Oklahoma Archaeology. American Antiquity 4:349-350.

1940 Comment on an Oklahoma Pictograph. American Antiquity 6:166.

1942a A Southern Oklahoma Copper Ornament. American Antiquity 7:400-403.

1942b The Legend of Abuska. Chronicles of Oklahoma 20: 255-256.

1942c Archaeological Remains in Platt National Park, Oklahoma. Society for American Archaeology Notebook 2:50-51.

Brooks, Robert L.

1987 The Arthur Site: Settlement and Subsistence Structure at a Washita River Phase Village. Oklahoma Archeological Survey, Studies in Oklahoma's Past 15, Norman. Oklahoma.

2002 The Manufacture and Distribution of Stone and Clay Pipes in the Turkey Creek and Washita River Phases, Central and Western Oklahoma. Paper presented at $60^{\text {th }}$ Annual Plains Conference, Oklahoma City, Oklahoma.

2010 Analyzing the Arkansas River Caddoan Cultural Landscape. Caddo Archeology Journal 20: 31-52.

2011 An Earspool from Near Ada, Pontotoc County, Oklahoma. Caddo Archeology Journal 21:163-167. 


\section{References Cited (cont.)}

Brooks, Robert L. and James E. Cox

2010 The Allcorn Site and Its Relationship to the Arkansas River Basin Caddoan Area. Oklahoma Anthropological Society, Bulletin LVIII: 25-46.

Brown, James A.

1996 The Spiro Ceremonial Center: The Archaeology of Arkansas Valley Caddoan Culture in Eastern Oklahoma. Memoirs of the Museum of Anthropology, University of Michigan, no. 29, Ann Arbor.

Brues, Alice M.

1957 Skeletal Material from the Nagle Site. Bulletin of the Oklahoma Anthropological Society 5:101-106.

Buehler, Kent V.

1982 Survey of Selected Archeological Sites in Pottawatomie and Pontotoc Counties: An Update. Manuscript on file, Oklahoma Archeological Survey, Norman, Oklahoma.

Cederstrand, J. R.

1996 Digital Geologic Map of the Ardmore-Sherman Quadrangle, South-Central Oklahoma. U. S. Geological Survey Open File Report 96-370. URL: http: ok.state.usgs.gov/gis/geology.

Davis, Edward and H. R. Antle

1936 A Historical and Archaic Study of the Tuskegee in Florida. Chronicles of Oklahoma 14:53-66.

Johnson, Kenneth

2006 Geomorphic Provinces. In Historical Atlas of Oklahoma, edited by Charles Robert Goins and Danny Goble, pp. 4-5, University of Oklahoma Press, Norman, Oklahoma.

Miser, Hugh

1934 Geological Map of Oklahoma. Oklahoma Geological Survey, Norman, Oklahoma.

Owsley, Douglas W.

1989 The History of Bioarchaeological Research in the Southern Great Plains. In From Clovis to Comanchero: Archaeological Overview of the Southern Great Plains, Jack L. Hofman, Robert L. Brooks, Joe S. Hays, Douglas W. Owsley, Richard L. Jantz, Murray K. Marks, and Mary H. Manheim. Arkansas Archeological Survey, Research Series No. 35.

Schaeffer, James B.

1956 News-East Central College Excavations. Newsletter, Oklahoma Anthropological Society V (5):5.

1957a East Central State College Dig. Newsletter, Oklahoma Anthropological Society V (7): 4-5.

1957b The Nagle Site, Ok-4. Bulletin of the Oklahoma Anthropological Society 5:93-100.

Woods, A. J.; J.M. Omernik, D.R. Butler, J.G. Ford, J.E. Henley, B.W. Hoagland, D.S. Arndt, and B.C. Moran 2005 Ecoregions of Oklahoma. U. S. Geological Survey, Reston, Virginia. 